\title{
Tauhid: Prinsip Keluarga dalam Islam (Problem Keluarga di Barat)
}

\author{
M. Saeful Amri* \& Tali Tulab** \\ Universitas Darussalam (UNIDA), Ponorogo \\ Universitas Islam Sultan Agung (UNISSULA), Semarang \\ Email: m.saeful.amri.sa@gmail.com
}

\begin{abstract}
Family is a special structure in society. According to Islamic teachings, the engagement contains both responsibility and mutual expectation. The value of compassion based on religion makes the family structure has a solid foundation. This is because the family structure and position is determined by Islamic law and not merely feeling. However, in the modern society, who tend to think and be pragmatic, the wedding just takes precedence as sexual function, reproduction and recreation. As a result, modern Western society is experiencing a major polemic of family problems. There are two main factors over the cracking of a family system in the modern State. First, because the marriage is only focused to seek pleasure rather than thinking about responsibility. So many families are divorced and experienced domestic violence. Second, because the breakup of a large family system intact. It affects the high number of suicide cases and rape among adolescents due to lack of attention from parents and families. Hence the modern society needs to make Islam a concept in the formation of the family. Because the system and the foundation is derived from the principle of Tawheed, which makes God as the maker of rules to run in everyday life.
\end{abstract}

Keywords: Islam, Western, Family.

* Program Kaderisasi Ulama (PKU) Gontor, Universitas Darussalam, Ponorogo.

** Dosen Program Studi Ahwal Syakhshiyyah, Jurusan Syariah, Fakultas Agama Islam, Universitas Islam Sultan Agung (UNISSULA), Semarang. 
96 M. Saeful Amri \& Tali Tulab

\begin{abstract}
Abstrak
Keluarga adalah suatu struktur dalam masyarakat yang bersifat khusus, saling mengikat satu sama lain. Menurut ajaran Islam, perikatan itu mengandung tanggung jawab dan sekaligus rasa saling memiliki dan saling berharap (mutual expectation). Nilai kasih sayang yang berdasarkan agama menjadikan struktur keluarga memiliki pondasi yang kokoh. Hal tersebut disebabkan struktur keluarga dan kedudukannya ditentukan oleh hukum Islam dan bukan semata-mata perasaan. Berbeda dengan masyarakat modern yang cenderung berfikir dan bersikap pragmatis, sehingga pernikahan lebih diutamakan sebagai fungsi seksual, reproduksi dan rekreasi. Akibatnya masyarakat Barat modern tengah mengalami polemik besar yaitu masalah keluarga. Ada dua faktor utama atas retaknya sistem sebuah keluarga di Negara modern tersebut. Pertama, sebab pernikahan yang hanya terfokus untuk mencari kesenangan daripada berpikir tentang tanggung jawab. Sehingga banyak keluarga yang bercerai dan mengalami kekerasan dalam rumah tangga. Kedua, sebab putusnya sistem keluarga besar yang utuh. Hal tersebut berdampak pada meningginya angka kasus bunuh diri serta pemerkosaan dikalangan remaja akibat kurangnya perhatian dari orang tua dan keluarga. Karenanya masyarakat modern perlu untuk menjadikan Islam sebagai konsep dalam pembentukan keluarga. Sebab sistem dan landasannya berasal dari prinsip Tauhid, yakni menjadikan Tuhan sebagai pembuat aturan untuk dijalankan dalam kehidupan seharihari.
\end{abstract}

Keywords: Islam, Barat, Keluarga.

Ulul Albab: Jurnal Studi dan Penelitian Hukum Islam 


\section{PENDAHULUAN}

Keluarga, ${ }^{1}$ dalam sistem kehidupan sosial menempati kedudukan yang sangat penting. ${ }^{2}$ Karena fungsi dari institusi keluarga menjadi tolak ukur kebahagiaan suatu masyarakat. ${ }^{3}$ Apabila fungsi ini tidak berjalan dengan baik, maka akan muncul persoalan-persoalan sosial yang tidak hanya berdampak pada keluarga tetapi juga pada masyarakat secara umum. ${ }^{4}$ Karenanya hampir seluruh budaya bangsa menempatkan

${ }^{1}$ Secara etimologis keluarga dalam istilah jawa terdiri dari dua kata yakni kawula dan warga. Kawula berarti abdi dan warga adalah anggota. Artinya kumpulan individu yang memiliki rasa pengabdian tanpa pamrih demi kepentingan seluruh individu yang bernanung di dalamnya. Keluarga adalah suatu kelompok yang ditandai oleh tempat tinggal bersama, kerja sama ekonomi, dan reproduksi yang dipersatukan oleh pertalian perkawinan atau adopsi yang disetujui secara sosial, yang saling berinteraksi sesuai dengan peran-peran sosialnya. Lihat Safrudin Aziz, Pendidikan Keluarga: Konsep dan Strategi, Yogyakarta: Penerbit Gava Media, 2015, h. 15.

2 Institusi keluarga merupakan satu-satunya wadah legal yang menghimpun laki-laki dan perempuan untuk hidup bersama. Selain itu, keluarga juga merupakan kesatuan terkecil yang bertanggung jawab mewujudkan terciptanya masyarakat yang damai dan berkeadaban. Oleh sebab itu, keluarga harus menjadi benteng yang terlindungi. Lihat Henry Shalahuddin dalam Buku Seri Kuliah, Islam, Gender, dan Keluarga tth, h. 37.

${ }^{3}$ Pasangan kata dari keluarga adalah bahagia, sehingga idiomnya menjadi keluarga bahagia. Maknanya, tujuan dari setiap orang yang membina rumah tangga adalah mencari kebahagiaan hidup. Jika seseorang gagal dalam karirnya diluar rumah, tetapi sukses membangun keluarga yang kokoh dan sejahtera, maka ia tetap dipandang sebagai orang yang sukses dan bahagia. Sebaliknya, orang yang sukses diluar rumah, tetapi keluarganya berantakan, maka ia tidak disebut orang yang beruntung, kegagalan dalam rumah tangganya akan tercermin diwajahnya, tercermin pula pada pola hidupnya yang tidak bahagia. Lihat Prof. Achmad Mubarak, Psikologi Keluarga, Malang: Madani, 2016, h. 114.

4 Secara umum fungsi keluarga meliputi pengaturan seksual, reproduksi, sosialisasi, pemeliharaan, penempatan anak dalam masyarakat, pemuas kebutuhan perseorangan, dan control sosial. Lihat Goode William J., The Family, terjemahan ke dalam bahasa Indoensia oleh Dra. Lailahanoum Hasyim, Jakarta: Penerbit PT Bina Aksara, 1983, h. 44-48. 
98 M. Saeful Amri \& Tali Tulab

kehidupan keluarga sebagai kehidupan yang sebenarnya. ${ }^{5}$ Biasanya, bangunan keluarga terbentuk oleh dua hal, pertama karena hubungan darah (natural blood ties) ${ }^{6}$ dan kedua karena adanya pernikahan (marriage). ${ }^{7}$

Di Barat, ${ }^{8}$ institusi keluarga sedang dalam keadaan sekarat. Sebab lembaga keluarga di pandang oleh kaum feminis sebagai musuh utama yang harus di hilangkan atau diperkecil peranannya. Karena keluarga merupakan cikal bakal lahirnya ketimpangan sosial yang berujung penindasan terhadap kaum perempuan. ${ }^{9}$ Sebab itu, kaum feminis menginginkan kesetaraan hak dan kewajiban antara suami-istri di dalam rumah tangga, tidak ada kewajiban bagi perempuan untuk mengurus rumah dan anak, ${ }^{10}$ perempuan bebas berkarir sebagaimana laki-laki, karena laki-laki dan perempuan adalah mitra dalam rumah

${ }^{5}$ Karena utuhnya suatu Negara terkait erat pada ketahanan keluarga, dan runtuhnya suatu bangsa barawal dari runtuhnya keluarga, semakin rentan dan rapuh institusi keluarga disuatu Negara maka akan berdampak pada stabilitas Negara tersebut. Lihat Syamsuddin Arif, Islam dan Diabolisme Intelektual, INSIST, 2017. h, 175.

${ }^{6}$ Muhammad Sochib, Pola Asuh Orangtua Dalam Membantu Anak Mengembangkan Disiplin Diri, Jakarta: Rineka Cipta, 1998, h. 17.

7 Puspitawati, H. Gender dan Keluarga: Konsep dan Realita di Indonesia. Bogor: PT IPB Press. 2012, h. 3.

${ }^{8}$ Yang dimaksud 'Barat' ialah peradaban yang dikembangkan oleh bangsa-bangsa Eropa dari peradaban Yunani Kuno yang di kawinkan dengan peradaban Romawi, dan disesuaikan dengan elemen-elemen kebudayaan bangsa Eropa terutamanya Jerman, Inggeris, dan Perancis. Prinsip-prinsip asas dalam Filsafat, Seni, Pendidikan, dan Pengetahuan diambil dari Yunani; prinsip-prinsip mengenai hukum dan ketatanegaraan diambil dari Romawi. Sementara agama Kristen yang berasal dari Asia Barat disesuaikan dengan budaya Barat. Lihat Hamid Fahmi Zarkahsyi, Liberalisasi Pemikiran Islam (Gerakan bersama Missionaris, Orientalis, dan Kolonialis, Ponorogo: CIOS-ISIDGontor, 2010, h. 4.

9 Siti Muslikhati, Feminisme dan Pemberdayaan Perempuan dalam Timbangan Islam, Jakarta: Gema Insani, 2004, h. 35.

${ }^{10}$ Ratna Megawangi, membiarkan berbeda? Sudut pandang baru tentang relasi gender, Bandung: Mizan, 1999, h. 11.

Ulul Albab: Jurnal Studi dan Penelitian Hukum Islam 
Tauhid: Prinsip Keluarga .... 99

tangga yang memiliki hak dan tanggung jawab yang sama. Akibatnya muncul persoalan baru dalam kehidupan keluarga di Barat; meningkatknya angka perceraian, kekerasan dalam rumah tangga (KDRT), bunuh diri dikalangan remaja, ${ }^{11}$ serta lahirnya berbagai bentuk kehidupan baru yang serba semrawut seperti kehidupan melajang, pasangan yang tinggal serumah tanpa menikah (cohibitation), pernikahan sesama jenis (LGBT), dan pasangan suami istri yang enggan untuk memiliki anak. ${ }^{12}$ Akibatnya negara-negara di Barat tengah mengalami krisis generasi dan hingga sampai saat ini keluarga menjadi isu penting yang masih terus didiskusikan.

Sebaliknya, Islam memandang pernikahan sebagai bagian yang sangat penting dalam kehidupan masyarakat. ${ }^{13}$ Pernikahan dianggap sebagai media pemenuhan tujuan Ilahi, sebab melalui pernikahan akan melahirkan hubungan manusia yang luas dan kompleks, antara satu sama lain saling mengikat, yang merupakan materi bagi sebagian besar dari ketentuan moral seperti kewajiban melahirkan keturunan, mencintai, mendukung, menghibur, menuntun, mendidik, menolong dan menemani. ${ }^{14}$ Karena dalam pernikahan mengandung tanggung jawab dan sekaligus rasa saling memiliki dan saling berharap (mutual expectation) antara satu dengan yang lainnya. Di samping itu, terjalin juga ikatan batih, yaitu ikatan sosial antara satu keluarga dengan keluarga yang lain, yang darinya timbul hak dan kewajiban yang harus berjalan secara seimbang. Itulah subtansi dari lembaga keluarga. ${ }^{15}$ Oleh sebab itu, pernikahan

${ }^{11}$ Elizabeth Diana Dewi, Bias Paham Feminisme Barat, Journal Islamia, Volume III No. 5, 2010, h. 91-96.

${ }^{12}$ Alvin Tofler, The third wave, Jakarta: PT Pantja Simpati, 1992. h. 84-87.

${ }^{13}$ Anshari Thayib, Struktur Rumah Tangga Islam, Risalah Gusti: ISBN 979-556-013-1, h. 10.

14 Isma'il Raji Al-Faruqi, Tauhid, (terjemah) Bandung: Penerbit Pustaka, 1988, h. 139

${ }^{15}$ Anshari Thayib, Struktur Rumah ...., h. 2. 
$100 \mid$ M. Saeful Amri \& Tali Tulab

sebagai media pembentuk keluarga harus dipenuhi guna penegakan tujuan Tuhan sebagaimana diatas.

Dari situ, tujuan daripada penulisan makalah ini adalah untuk mendeskripsikan prinsip-prinsip tuhan dalam pembentukan keluarga, khususnya keluarga muslim, serta mengkomparasikannya dengan masalah keluarga yang tengah dihadapi oleh institusi keluarga di Barat. untuk kemudian ditarik kesimpulan dengan mengajukan sebuah pertanyaan, "apakah masih ada bangunan keluarga di Barat?"

\section{Tauhid Prinsip Keluarga Dalam Islam}

\section{a) Urgensi Berkeluarga}

Dalam sebuah riwayah menyebutkan bahwa ketika Adam masih sendirian diawal kehidupannya ia merasa kesepian, maka Allah menciptakan teman berlawanan jenis, Hawa, yang kemudian menjadi istrinya. ${ }^{16}$ Dari sepasang manusia inilah kemudia berkembang biak menjadi keluargakeluarga baru lalu menyebar keseluruh bumi. Kecenderungan manusia untuk berkeluarga merupakan naluri yang diwariskan secara genetika agar kelangsungan generasi spesies manusia tetap terjaga. Syariat islam telah mengatur kecenderungan naluri itu agar tidak liar, brutal, dan tak bermartabat melalui lembaga pernikahan. ${ }^{17}$ Pernikahan yang sah menurut syariah merupakan awal dari pembentukan keluarga sakinah sepanjang suami dan istri terus menjalankan hak dan kewajibannya masing-masing.

b) Tujuan Membentuk Keluarga

Secara Bahasa, asal kata nikah adalah na-ka-ha berarti Indamma (bergabung), jama'a, wata'un (hubungan kelamin),

${ }^{16}$ Departemen Agama RI, Membangun Keluarga Harmoni (Tafsir AlQur'an Tematik), Jakarta: Departemen Agama RI, 2008, h. 1.

${ }^{17}$ Anshari Thayib, Struktur Keluarga Muslim, Risalah Gusti, ISBN 979-556-013-1, h. 21.

Ulul Albab: Jurnal Studi dan Penelitian Hukum Islam 
Tauhid: Prinsip Keluarga .... $\mid 101$

'aqdun (perjanjian). ${ }^{18}$ Sedangkan makna nikah secara terminologis:

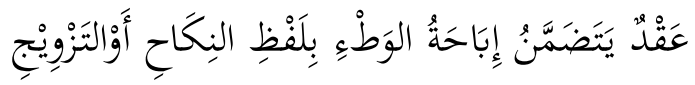

"Akad atau perjanjian yang mengandung maksud membolehkan hubungan kelamin dengan menggunakan lafadz na-ka-ha atau za-wa-ja" ${ }^{19}$

Ibrahim Hosen mengartikan nikah sebagai sebagai aqad yang dengannya menjadi halal hubungan kelamin antara pria dan wanita. ${ }^{20}$ Sedangkan Sajuti Thalib, mengartikannya sebagai suatu perjanjian yang suci, kuat dan kokoh untuk hidup bersama secara sah antara seorang laki-laki dengan seorang perempuan

${ }^{18}$ Amir Syarifuddin, Hukum Perkawinan Islam di Indonesia (Antara Figh Munakahat dan Undang-undang Perkawinan), Jakarta: Kencana Prenamedia Group, 2006, h. 36.

${ }^{19}$ Ada tiga kata kunci dari definisi tersebut diatas, yaitu 'aqada, yatadhammanu, dan an-nikah. Penggunaan kata 'aqada untuk menjelaskan bahwa perkawinan itu adalah suatu perjanjian yang dibuat oleh orang-orang yang terlibat dalam perkawinan. Perkawinan itu dibuat dalam bentuk akad karena ia adalah peristiwa hukum, bukan peristiwa biologis atau semata-mata hubungan kelamin antara laki-laki dan perempuan. Penggunaan ungkapan yatadhammanu ibahah al-Wata' mengandung maksud membolehkan hubungan kelamin, karena pada dasarnya hubungan laki-laki dan perempuan adalah terlarang, kecuali ada hal-hal yang membolehkannya secara syarak. Diantara hal-hal yang membolehkan hubungan kelamin itu adalah adanya akad nikah diantara keduanya. Dengan demikian, akad itu adalah sesuatu usaha untuk membolehkan sesuatu yang asalnya tidak boleh kemudian boleh dengan adanya akad. Menggunakan kata bi lafdzin nikah, bahwa akad membolehkan hubungan kelamin antara laki-laki dan perempuan dengan menggunakan kata $n a-k a-h a$ atau za-wa-ja. Dari situ dapat difahami bahwa hakikat utama dari suatu perkawinan yaitu kebolehan melakukan hubungan kelamin setelah berlangsungnya hubungan pernikahan itu. Departemen Agama RI, Membangun Keluarga Harmoni (Tafsir Al-Qur'an Tematik), Jakarta: Departemen Agama RI, 2008, h. 30.

${ }^{20}$ Hosen Ibrahim, Figh Perbandingan dalam Masalah Nikah dan Rujuk, Jakarta: Thya Ulumuddin, 1971, h. 65. 
$102 \mid$ M. Saeful Amri \& Tali Tulab

untuk membentuk keluarga yang kekal, santun-menyantuni, kasih-mengasihi, tenteram dan bahagia. ${ }^{21}$

Menurut al-Faruqi, pernikahan merupakan pemenuhan terhadap tujuan Tuhan agar dari pernikahan itu melahirkan keturunan. Sebab pernikahan dalam kacamata Islam merupakan perisai suci untuk mengahalalkan laki-laki dan perempuan melakaukan hubungan seksual sehingga mereka tidak terjerumus kedalam perbuatan tercela. Adapun tujuan daripada pernikahan tersebut adalah untuk melahirkan keturunan, mencintai, mendukung, menghibur, menuntun, mendidik, menolong, dan menemani. ${ }^{22}$ Oleh karena itu, pernikahan bukan hanya bertujuan untuk melakukan hubungan seksual dan melahirkan keturunan semata, ${ }^{23}$ tetapi lebih dari itu, yakni untuk memenuhi kebutuhan manusia dari sisi rohaninya yaitu membentuk keluarga sakinah yang dilandasi atas mawaddah dan rahmah. Sebagaimana disebutkan di Dalam al-Qur'an, Allah Berfirman:24

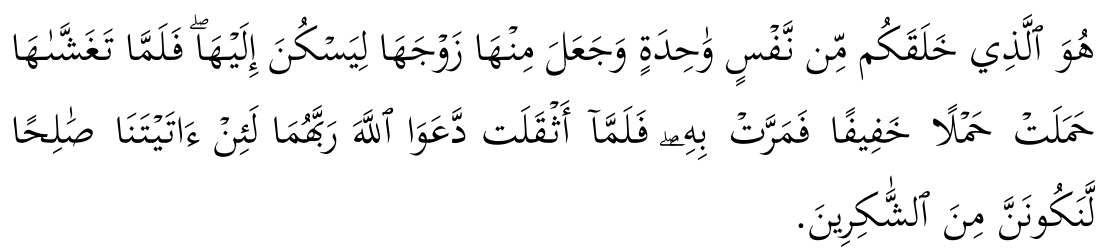

Artinya:

Dialah yang menciptakan kamu dari diri yang satu dan dari padanya Dia menciptakan isterinya, agar Dia merasa senang kepadanya. ke III), Jakarta: 1997.

${ }^{21}$ Thalib Sajuti, Kuliah Hukum Islam II Pada Fakultas Hukum UI (Kuliah

22 Isma'il Raji Al-Faruqi, Tauhid, (terjemah) Bandung: Penerbit Pustaka, 1988, h. 139-140.

${ }^{23}$ Jika pernikahan hanya bertujuan untuk memenuhi kebutuhan seksual dan melahirkan keturunan, maka dalam tataran ini, manusia belum dapat dibedakan dengan binatang. Departemen Agama RI, Membangun Keluarga Harmoni (Tafsir Al-Qur'an Tematik), Jakarta: Departemen Agama RI, $2008, \mathrm{~h}$.

${ }^{24}$ al-A'raf: 189.

Ulul Albab: Jurnal Studi dan Penelitian Hukum Islam 


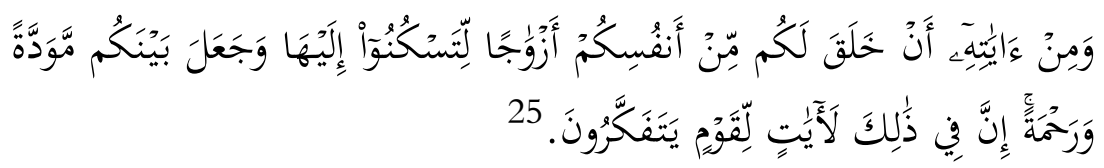

Artinya:

"Dan di antara tanda-tanda kekuasaan-Nya ialah Dia menciptakan untukmu isteri-isteri dari jenismu sendiri, supaya kamu cenderung dan merasa tenteram kepadanya, dan dijadikan-Nya diantaramu rasa kasih dan sayang. Sesungguhnya pada yang demikian itu benar-benar terdapat tanda-tanda bagi kaum yang berfikir".

Ayat-ayat di atas mengandung pelajaran penting bahwa manusia adalah makhluk yang memiliki kemampuan untuk berketurunan sebagaimana makhluk hidup lainnya. Hanya saja dalam tataran prosesnya, manusia berbeda dengan binatang. Ada aturan yang harus dipenuhi sebelumnya, yakni melalui sebuah perkawinan yang sah menurut agama. Dari situlah manusia akan memperoleh ketenangan dan ketentraman (sakinah). meskipun sebelumnya keduanya tidak saling mengenal secara mendalam.

Kata sakinah disini tidak diungkapkan dengan kata benda (Isim), akan tetapi dengan bentuk kata kerja (taskunu/yaskunu), yang menunjukkan arti hudus (kejadian) dan tajaddud (memperbaharui). Artinya, sakinah bukan sesuatu yang sudah jadi atau sekali jadi, namun ia harus diupayakan secara sungguh-sungguh (mujahadah) dan terus menerus diperbaharui, sebab ia bersifat dinamis yang senantiasa timbul tenggelam. Atau dengan kata lain, sebuah perkawinan yang sakinah bukan berarti sebuah perkawinan yang tidak pernah ada masalah, sebab perkawinan bagaikan bahtera yang mengarungi lautan, dan setenang-tenangnya lautan pasti ada ombak. Namun demikian, gambaran sederhana dari keluarga sakinah adalah jika masing-masing pihak dengan penuh kesungguhan berusaha mengatasi masalah yang timbul, dengan didasarkan pada

${ }^{25}$ Al-Rum: 21. 
104 M. Saeful Amri \& Tali Tulab

keinginan yang kuat untuk menuju kepada ketenangan dan ketentraman jiwa tersebut, sebagaimana diisyaratkan oleh ayat di atas. ${ }^{26}$

Di samping itu, Al-Qur'an juga menyatakan bahwa sakinah tersebut dimasukkan oleh Allah melalui kalbu. Artinya, kedua belah pihak, yakni suami dan istri, harus mempersiapkan kalbunya terlebih dahulu dengan kesabaran dan ketakwaan. Dalam hal ini, Quraish Shihab menyatakan bahwa persiapan kalbu harus melalui beberapa fase, bermula dari mengosongkan kalbu dari sifat-sifat tercela (takhalli), dengan cara menyadari atas segala kesalahan dan dosa ytang pernah diperbuat, disertai tekad yang kuat untuk tidak mengulanginya dan berusaha menghindarinya. Disusul dengan perjuangan/mujahadah untuk melawan sifat-sifat tercela tersebut dengan cara mengedepankan sifat-sifat terpuji (tahalli), seperti melawan kekikiran dengan kedermawanan, kecerobohan dengan keberanian, egoism dengan pengorbanan, sambil terus memohon pertolongan dari Allah Swt. ${ }^{27}$

\section{c) Hak dan Kewajiban Anggota Keluarga}

Pada dasarnya tujuan pernikahan dalam Islam ialah untuk membentuk keluarga harmonis (sakinah) yang dilandasi dengan perasaan kasih dan sayang (mawaddah, warahmah). Salah satu cara supaya keharmonisan itu terbangun dan tetap terjaga adalah dengan adanya hak $^{28}$ dan kewajiban ${ }^{29}$ diantara masingmasing anggota keluarga. Adanya hak dan kewajiban ini bertujuan agar masing-masing anggota sadar akan kewajibannya kepada yang lain, sehingga dengan pelaksanaan kewajiban tersebut hak anggota yang lain pun akan terpenuhi.

${ }^{26}$ Departemen Agama RI, Membangun Keluarga Harmoni (Tafsir AlQur'an Tematik), Jakarta: Departemen Agama RI, 2008, h. 73.

${ }^{27}$ Quraish Shihab, Pengantin Al-Qur'an, Jakarta: Lentera Hati, 2007, h. 82.

${ }^{28}$ Apa-apa yang diterima oleh seseorang dari orang lain.

${ }^{29}$ Apa-apa yang mesti dilakukan oleh seseorang terhadap orang lain.

Ulul Albab: Jurnal Studi dan Penelitian Hukum Islam 
Tauhid: Prinsip Keluarga .... $\mid 105$

Menurut Al-Faruqi, Islam menganggap laki-laki dan perempuan diciptakan untuk prinsip-prinsip yang berbeda tetapi saling melengkapi. Fungsi ibu, sebagai pengatur rumah tangga dan pengasuh anak, dan fungsi ayah, sebagai pelindung, pencari nafkah dan pemikul seluruh tanggung jawab keseluruhan yang menuntut syarat-syarat fisik, psikis dan emosional yang berlainan dari laki-laki dan perempuan. Islam menganggap pembedaan ini perlu demi pemenuhan diri dari kedua jenis kelamin. Perbedaan peranan sama sekali bukanlah diskriminasi atau degredasi. Kedua peranan tersebut sama-sama tunduk dibawah norma-norma agama dan etika; dan karenanya membutuhkan kecerdasan, bakat, enerji dan usaha yang sungguh-sungguh dari kedua jenis kelamin. ${ }^{30}$

Karena itu adanya hak dan kewajiban pada setiap anggota keluarga juga untuk menjaga keharmonisan sekaligus untuk menghormati dan memberikan kasih sayang kepada anggota keluarga yang lain. Islam, melalui Al-Qur'an dan Sunnah menyatakan bahwa dalam keluarga, antara suami dan Istri serta antara anak dan orang tua, masing-masing memiliki hak dan kewajiban. ${ }^{31}$ Dengan demikian, adanya hak dan kewajiban ini juga merupakan sarana interaksi dan relasi antar anggota keluarga supaya tercipta komunikasi dan pergaulan yang baik (Mu'asyarah bil-ma'ruf) ${ }^{32}$ sehingga tercipta rasa kasih sayang dalam keluarga.

30 Isma'il Raji Al-Faruqi, Tauhid, (terjemah) Bandung: Penerbit Pustaka, 1988, h. 142

${ }^{31}$ Departemen Agama RI, Membangun Keluarga Harmoni (Tafsir AlQur'an Tematik), Jakarta: Departemen Agama RI, 2008, h. 104-105.

${ }^{32}$ Pada dasarnya, para anggota keluarga dapat mengkompromikan dan memusyawarahkan secara bersama dengan tetap mengacu pada terciptanya kehidupan yang harmonis (sakinah) sebagai tujuan utama dari pernikahan. Sehingga $M u^{\prime} a s y a r a h$ bil-ma'ruf sebagai landasan dari hak dan kewajiban yang bersifat fleksibel. 
106 M. Saeful Amri \& Tali Tulab

\section{d) Hak Dan Kewajiban Suami Istri}

Hak dan kewajiban suami istri pada dasarnya seimbang, sehingga prinsip hubungan antara suami dan istri dalam keluarga adalah adanya keseimbangan dan kesepadanan (attawazub wat-takafu') antara keduanya. Keseimbangan antara hak dan kewajiban ini antara lain dinyatakan oleh Al-Qur'an: ${ }^{33}$

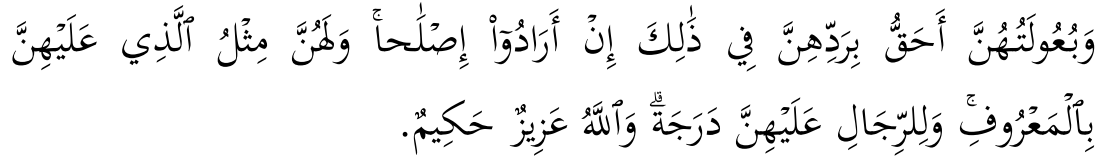

Artinya:

"Dan mereka (para wanita) mempunyai hak yang seimbang dengan kewajibannya menurut cara yang ma'ruf. akan tetapi para suami, mempunyai satu tingkatan kelebihan daripada isterinya ${ }^{34}$ dan Allah Maha Perkasa lagi Maha Bijaksana". (Q.S, al-Baqarah: 228)

Ayat tersebut memberi pengertian bahwa istri memiliki 'hak' yang wajib dipenuhi oleh suami, begitu pula dengan 'hak' yang dimiliki suami dan harus dipenuhi oleh istri, yang keduanya dilaksanakan dengan cara yang ma'ruf. Kewajiban dan hak antara suami dan istri ini umumnya dapat dibagi menjadi empat bagian, yaitu kewajiban suami yang merupakan hak istri, ${ }^{35}$ kewajiban istri yang merupakan hak suami, hak bersama antara suami dan istri, ${ }^{36}$ serta kewajiban bersama antara suami dan istri. ${ }^{37}$ Setelah lahirnya seorang anak maka muncul hak dan kewajiban baru yakni hak dan kewajiban antara anak dan orang tua.

${ }^{33}$ Al-Baqarah: 228.

${ }^{34} \mathrm{Hal}$ ini disebabkan karena suami bertanggung jawab terhadap keselamatan dan Kesejahteraan rumah tangga (Lihat surat An Nisaa' ayat 34).

${ }^{35}$ Departemen Agama RI, Membangun Keluarga Harmoni (Tafsir AlQur'an Tematik), Jakarta: Departemen Agama RI, 2008, h. 1

${ }^{36}$ Azar Basyir, Hukum Perkawinan Islam, yogyakarta: perpustakaan fakultas hukum UII, 1996, h. 49.

${ }^{37}$ Amir Syarifuddin, Hukum Perkawinan Islam di Indonesia (Antara Fiqh Munakahat dan Undang-undang Perkawinan), Jakarta: Kencana Prenamedia Group, 2006, h. 160.

Ulul Albab: Jurnal Studi dan Penelitian Hukum Islam 
Tauhid: Prinsip Keluarga .... $\mid 107$

\section{e) Kewajiban suami}

Suami dinyatakan secara tekstual dalam al-Qur'an adalah sebagai pelindung (Qawwam) bagi istri. Dari situ, para ulama kemudian menetapkan bahwa suami adalah kepala keluarga. Ayat tersebut menyatakan bahwa suami adalah pelindung bagi perempuan adalah karena dua hal, yaitu pertama, hal yang besifat natural karena pemberian (wahbi) dari Allah ini berupa bentuk fisik dan laki-laki yang secara umum lebih kuat dari perempuan. Kemudian yang kedua adalah hal yang bersifat sosial karena merupakan sesuatu yang diuasahakan (kasbi). Ini berupa harta benda yang dinafkahkan bagi anggota keluarga yang lain, yaitu istri dan anak.

Dalam beberapa literatur kewajiban suami sebagai kepala rumah tangga ini biasaya dibagi menjadi dua, yaitu kewajiban yang berkaitan dengan harta benda (maliyyah) seperti nafkah, dan kewajiban yang tidak berkaitan dengan harta benda (gair maliyyah) seperti memperlakukan istri dengan baik. Apabila pembagian ini diperinci secara singkat, maka kewajiban suami terhadap istrinya yang berkitan dengan benda terbagi menjadi dua, yang pertama adalah mahar, ${ }^{38}$ sebagimana yang dijelaskan dalam surat an-Nisa' ayat $4^{39}$ dan $24^{40}$, dan yang kedua ialah pemberian harta benda untuk keperluan hidup yang biasa disebut nafkah (nafaqah).

38 Mahar atau lebih dikenal dengan sebutan maskawin adalah pemberian wajib dari suami kepada istri, dan merupakan hak penuh istri yang tidak boleh diganggu oleh suami. Suami hanya dibenarkan ikut makan maskawin tersebut apabila diberikan oleh istri dengan sukarela. Lihat Azar Basyir, Hukum Perkawinan Islam, yogyakarta: perpustakaan fakultas hukum UII, 1996, h. 50

${ }^{39}$ Surat An-Nisa ayat 4

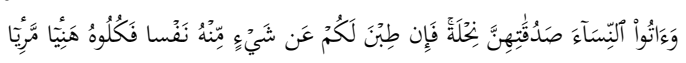

${ }^{40}$ Surat An-Nisa ayat 24

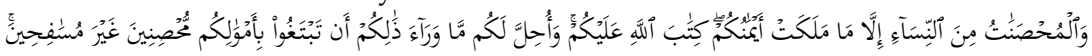

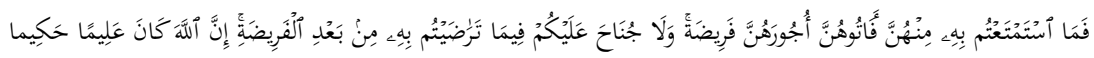


108 M. Saeful Amri \& Tali Tulab

Nafkah suami terhadap istrinya meliputi segala keperluan hidup, baik makanan, tempat tinggal, dan segala pelayanannya, yang tentu saja disesuaikan dengan kemampuan suami dan adat kebiasaan masyarakat setempat. Ayat Al-Qur'an dalam pemberian nafkah oleh suami terhadap istrinya sangat menekankan pada kelayakan menurut masing-masing masyarakat (al-ma'ruf) dan juga disesuaikan dengan kemampuan suami (al-wus'u).

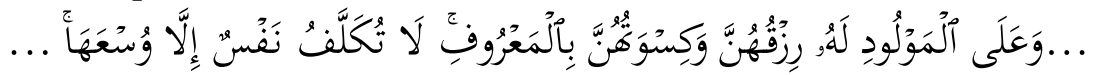

Artinya:

"Kewajiban ayah memberi Makan dan pakaian kepada Para ibu dengan cara ma'ruf. seseorang tidak dibebani melainkan menurut kadar kesanggupannya". 41

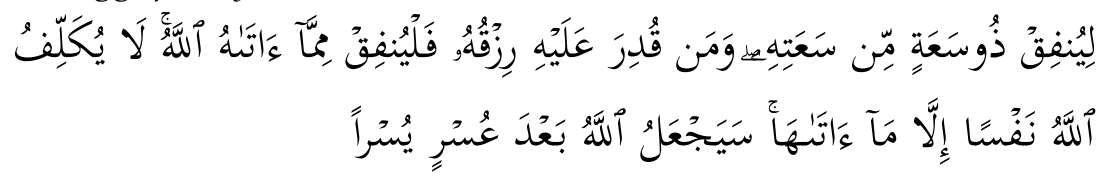

Artinya:

"Hendaklah orang yang mampu memberi nafkah menurut kemampuannya. dan orang yang disempitkan rezkinya hendaklah memberi nafkah dari harta yang diberikan Allah kepadanya. Allah tidak memikulkan beban kepada seseorang melainkan sekedar apa yang Allah berikan kepadanya. Allah kelak akan memberikan kelapangan sesudah kesempitan". 42

Ayat tersebut menyebut suami yang berkewajiban meberikan nafkah kepada istrinya dengan istilah al-maulud lahu (pemilik anak yang dllahirkan). Ini berarti, bahwa antara nafkah dan wiladah (melahirkan, salah satu proses reproduksi yang dialami perempuan) memiliki kaitan yang sangat erat. Sedangkan pernyataan Al-Qur'an tentang pelaksanaan pemberian nafkah dengan cara yang $m a^{\prime} r u f$ maksudnya ialah

\footnotetext{
${ }^{41}$ Al-Baqarah: 233.

${ }^{42}$ Al-Thalaq: 7.
}

Ulul Albab: Jurnal Studi dan Penelitian Hukum Islam 
\begin{tabular}{l|l} 
Tauhid: Prinsip Keluarga .... & 109
\end{tabular}

menurut kelayakan dan kepatutan, tidak saja sesuai dengan konteks masyarakat, tetapi juga sesuai dengan konteks internal keluarga. Kewajiban dan hak suami istri dapat dilaksanakan secara fleksibel, karena yang terpenting adalah terwujudnya tujuan pernikahan, yaitu membentuk keluarga harmonis yang satu sama lain saling menyayangi dan menghormati. ${ }^{43}$

Kedua, kewajiban suami terhadap istrinya yang tidak berkaitan dengan kebendaan (gair maliyyah) diantaranya yang pertama ialah menggauli istri dengan cara yang 'makruf'. Hal ini sesuai dengan firman Allah dalam surat an-Nisa ayat 19:

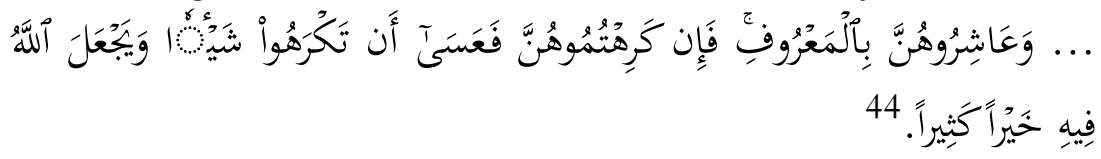

Artinya:

"Pergaulilah mereka (isteri-isterimu) secara baik. kemudian bila kamu tidak menyukai mereka, (maka bersabarlah) karena mungkin kamu tidak menyukai sesuatu, Padahal Allah menjadikan padanya kebaikan yang banyak".

Yang dimaksud dengan pergaulan disini secara khusus adalah pergaulan suami istri termasuk hal-hal yang berkenaan dengan pemenuhan kebutuhan seksual. Menurut Azar Basyir menggauli istri dengan cara ma'ruf itu mencakup tiga hal: pertama, sikap menghormati, menghargai, dan perlakuanperlakuan yang baik, serta meningkatkan taraf hidupnya dalam bidang-bidang agama, akhlak, dan ilmu pengetahuan yang diperlukan. Kedua, menjaga dan melindungi nama baik istri. Ketiga, memenuhi kebutuhan kodrat biologisnya. ${ }^{45}$

Selanjutnya suami berkewajiban menjaganya dari segala sesuatu yang mungkin melibatkannya pada suatu perbuatan

${ }^{43}$ Departemen Agama RI, Membangun Keluarga Harmoni (Tafsir AlQur'an Tematik), Jakarta: Departemen Agama RI, 2008, h. 110-111

${ }^{44}$ Al-Nisa: 19.

45 Lihat Azar Basyir, Hukum Perkawinan Islam, yogyakarta: perpustakaan fakultas hukum UII, 1996, h. 54-56. 
110 M. Saeful Amri \& Tali Tulab

dosa dan maksiat atau ditimpa oleh sesuatu kesulitan dan mara bahaya.

$$
\text { قُوْ أَنْفُسِكُمْ وَأَهْلْيْكُمْ نَارًا }
$$

\section{Peliharalah dirimu dan peliharalah diri keluargamu dari neraka}

Dalam ayat ini terkandung suruhan untuk menjaga kehidupan beragama istrinya, sehingga sang istri tetap menjalankan ajaran agama; dan menjauhkan istrinya dari segala sesuatu yang dapat menimbulkan kemarahan Allah. Untuk itu suami wajib memberikan pendidikan agama dan pendidikan lain yang berguna bagi istri dalam kedudukannya sebagai istri.

Terakhir, suami wajib memberikan rasa tenang kepada istrinya, serta memberikan cinta dan kasih sayang kepadanya agar tujuan dari pernikahan tersebut dapat terwujud yaitu kehidupan keluarga yang harmonis (sakinah), mawaddah, dan rahmah.

\section{f) Kewajiban Istri}

Kewajiban istri terhadap suaminya tidak ada yang berbentuk materi secara langsung, tetapi dalam bentuk nonmateri ${ }^{46}$ seperti, taat dan patuh kepada suaminya, sebagaimana firman Allah dalam surat an-Nisa ayat 34:

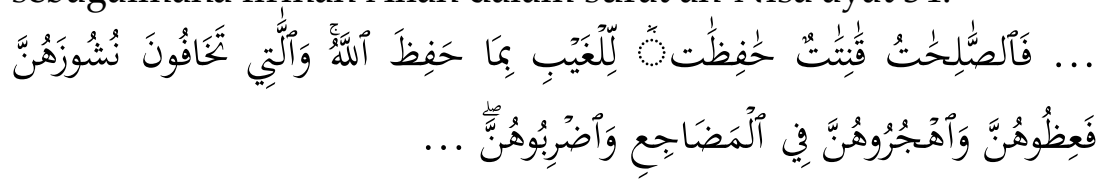

46 Menurut Amir Syarifuddin, kewajiban Isteri kepada suami diantaranya ialah sebagai berikut: 1 . Memberikan rasa tenang dalam rumah tangga untuk suaminya: memberikan rasa cinta dan sayang; 2 . Menggauli suaminya secara layak sesuai kodratnya; 3 . Taat dan patuh kepada suaminya; 4. Menjaga dirinya dan menjaga harta suaminya bila suaminya sedang tidak ada dirumah; 5. Menjauhkan dirinya dari segala yang tidak disenangi oleh suaminya; 6.Menjauhkan dirinya dari memperlihatkan muka yang tidak enak dipandang dan suara yang tidak enak didengar. Lihat, Amir Syarifuddin, Hukum Perkawinan Islam di Indonesia (Antara Fiqh Munakahat dan Undangundang Perkawinan), Jakarta: Kencana Prenamedia Group, 2006, h. 162-163.

Ulul Albab: Jurnal Studi dan Penelitian Hukum Islam 
Tauhid: Prinsip Keluarga .... $\mid 111$

Artinya:

"Perempuan-perempuan yang saleh ialah perempuan yang taat kepada Allah (dan patuh kepada suami) memelihara diri ketika suaminya tidak ada oleh karena Allah telah memelihara mereka".

Mematuhi suami disini mengandung arti mengikuti apa yang dipertintahkannya dan menghentikan apa-apa yang dilarangnya, selama suruhan dan larangan tesebut tidak menyalahi ketentuan agama. Bila larangan dan suruhannya itu bertentangan dengan ajaran agama, maka tidak ada kewajiban bagi istri untuk mengikutinya, agaimana sabda nabi saw:

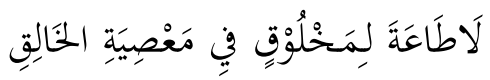

Tidak ada kewajiban taat kepada siapapun bila disuruh untuk berbuat maksiat kepada Allah

Menurut Azar basyir, isi dari pemaknaan taat sebagaimana tersebut dalam ayat diatas adalah sebagai berikut: pertama, istri supaya tinggal bersama suami dirumah yang telah disediakan. Kedua, taat kepada perintah-perintah suami, kecuali apabila melanggar larangan Allah. Ketiga, berdiam di rumah, tidak keluar kecuali dengan izin suami. Keempat, tidak menerima masuknya seseorang tanpa izin suami. Kelima, kewajiban taat yang meliputi empat hal tersebut disertai syarat-syarat yang tidak memberatkan istri. ${ }^{47}$

Selain itu istri juga harus mengupayakan untuk melaksanakan fungsi reproduksi secara baik dan sehat. mengingat nafkah dipandang sebagai kewajiban suami sebagai imbangan dari fungsi reproduksi perempuan yang mengandung, melahirkan, dan menyusui, yang secara kodrati memang hanya bisa dilakukan oleh perempuan. Sementara itu, penentuan untuk memiliki keturunan atau tidak, kapan waktunya, dan jumlah keturunannya berapa adalah hak berdua

47 Azar Basyir, Hukum Perkawinan Islam, yogyakarta: perpustakaan fakultas hukum UII, 1996, h. 57. 
112 M. Saeful Amri \& Tali Tulab

dari suami dan istri. Ketiga hal tersebut, semuanya dapat di musyawarahkan antara suami dan istri. ${ }^{48}$

\section{g) Hak dan Kewajiban Bersama Suami-Istri}

Pernikahan merupakan komitmen dua belah pihak untuk menjalani kehidupan bersama dengan membentuk keluarga. Untuk mendapatkan kebahagiaan dalam keluarga perlu adanya niat dan usaha dari kedua belah pihak. Sehingga segala hal yang mengarah pada pembentukan keharmonisan keluarga seperti saling setia, menjaga rahasia keluarga, saling membantu dan menyayangi, merupakan kewajiban dan hak bersama suami dan istri. Menurut syafrudin, bentuknya ada tiga: Pertama, bolehnya bergaul dan bersenang-senang di antara keduanya. Inilah hakekat sebenarnya dari sebuah perkawinan. Kedua, timbulnya hubungan suami dengan keluarga istrinya dan sebaliknya hubungan istri dengan keluarga suaminya. Ketiga, hubungan saling mewarisi di antara suami istri. Setiap pihak berhak mewarisi pihak yang lain bila terjadi kematian ${ }^{49}$ Dengan demikian, keduanya harus berupaya menjalin dan memelihara relasi, hubungan, dan pergaulan yang baik (mu'asyirah bil-ma'ruf) di antara mereka. Dalam Al-Qur'an Allah berfitman:

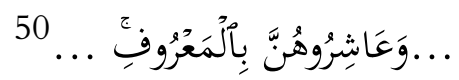

Artinya:

"Pergaulilah istrimu dengan cara yang baik".

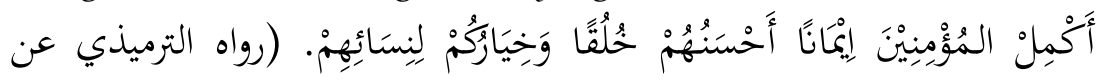

عائشة)

48 Asy-Syuura: 38: "sedang urusan mereka (diputuskan) dengan musyawarat antara mereka."

${ }^{49}$ Amir Syarifuddin, Hukum Perkawinan Islam di Indonesia (Antara Fiqh Munakahat dan Undang-undang Perkawinan), Jakarta: Kencana Prenamedia Group, 2006, h. 163.

${ }^{50}$ Al-Nisa: 19.

Ulul Albab: Jurnal Studi dan Penelitian Hukum Islam 
\begin{tabular}{l|l} 
Tauhid: Prinsip Keluarga .... & 113
\end{tabular}

Artinya:

Orang mukmin yang paling sempurna imannya adalah yang paling baik akhlaknya, dan sebaik-baik kamu adalah yang paling baik terhadap istri. (Riwayat at-Tirmidzi dari 'Aisyah)

Ayat al-Qur'an dan hadis Nabi diatas, ialah perintah kepada laki-laki untuk bergaul dan berbuat baik terhadap istrinya. Seruan tersebut diberikan kepada suami karena pada masi Nabi budaya yang dominan adalah budaya patriarkhi, sehingga perempuan masih tersubordinasi. Dalam konteks seperti itu kemudian ayat al-Qur'an dan hadis tersebut menyeru suami untuk bergaul secara baik dengan istrinya. Ini menunjukkan bahwa islam menganjurkan penghormatan kepada perempuan demi untuk kesetaraan, selain itu seruan tersebut juga berlaku sebaliknya, yakni anjuran kepada istri untuk bergaul secara baik dengan suaminya. ${ }^{51}$ Sebab suami istri itu masing-masing menjadi pakaian bagi yang lainnya, sebagai disebutkan dalam Al-Quran surat al-Baqarah ayat 187:

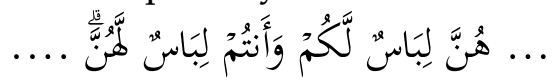

Artinya:

"Mereka adalah pakaian bagimu, dan kamu adalah pakaian bagi mereka".

Ayat ini menegaskan bahwa hubungan seksual adalah kepentingan berdua, bukan hanya kepentingan suami sedang istri hanya melayani, dan sebaliknya, hanya kepentingan istri sedang suami hanya melayani. Imam Al-Ghazali menyatakan bahwa hubungan seksual itu tidak hanya berfungsi untuk meneruskan ketrurunan, tetapi yang pertama kali adalah berfungsi untuk kesenangan. ${ }^{52}$ Ini berarti bahwa istri, sebagaimana suami, harus juga menikmati hubungan seksual.

${ }^{51}$ Departemen Agama RI, Membangun Keluarga Harmoni (Tafsir AlQur'an Tematik), Jakarta: Departemen Agama RI, 2008, h. 110-111

${ }^{52}$ Pernyataan al-Ghazali tersebut adalah: 
$114 \mid$ M. Saeful Amri \& Tali Tulab

Sedangkan kewajiban keduanya secara bersama setelah terjadinya pernikahan itu adalah: Pertama, memelihara dan mendidik anak keturunan yang lahir dari perkawinan tersebut. Kedua, Memelihara kehidupan rumah tangga yang sakinah, mawaddah, dan rahmah.

\section{h) Kewajiban dan Hak Anak-Orang Tua}

Salah satu tujuan dari pernikahan adalah meneruskan keturunan, yaitu dengan adanya anak. dengan adanya anak berarti hubungan dan relasi dalam keluarga bertambah, tidak hanya antara suami dan istri, tetapi juga antara orang tua dan anak. dalam Islam adanya pengaturan kewajiban dan hak antara orang tua dan anak pada dasarnya adalah dalam rangka merealisasikan tujuan pernikahan, yaitu membentuk keluarga yang harmonis dan bahagia.

1. Kewajiban Orang Tua

Sejak dalam kandungan, menurut para ulama, anak sudah dapat memiliki hak walaupun belum menerima kewajiban. Hak yang dimiliki anak dalam kandungan antara lain hak waris, hak wasiat, dan hak memiliki harta benda. ${ }^{53}$ Ini menunjukkan bahwa kasih sayang orang tua itu harus diberikan sejak anak masih dalam kandungan, baik dalam bentuk perawatan atau pemantauan kesehatan janin secara fisik maupun penerimaannya akan kehadirannya secara psikologis. ${ }^{54}$

اعلم أن الشهوة الوقاع سلطت على الانسان لفائدتين احداهما أن يدرك لذته فيقيس به لذته الوجود الأخرة. الفائدة الثانية

بقاء النسل ودوامه فهذه فائدةما

Ketahuilah bahwa hubungan seksual yang dilakukan manusia memiliki dua kemanfaatan; pertama, untuk mencapai kesenangan sehingga ia dapat menganalogikannya dengan kesenangan akhirat, dan kedua, untuk melanggengkan keturunan dan eksistensi manusia. Inilah manfaat dari hubungan seksual. Abu Hamid al-Ghazali, Ihya 'Ulumud-Din (t,t: t.p, t.h), jilid III, h. 107.

${ }^{53}$ Departemen Agama RI, Membangun Keluarga Harmoni (Tafsir AlQur'an Tematik), Jakarta: Departemen Agama RI, 2008, h. 120

54 Menurut safrudin Aziz, dalam buku pendidikan keluaraga, kewajiban orang tua yang sekaligus merupakan hak bagi anak pada hakikarnya mencakup tiga aspek, yaitu spiritual, sosial, dan emosional.

Ulul Albab: Jurnal Studi dan Penelitian Hukum Islam 
\begin{tabular}{l|l} 
Tauhid: Prinsip Keluarga .... & 115
\end{tabular}

Karena itulah dalam Islam, anak sejak dalam kandungan sampai menjelang dewasa memiliki hak perawatan dan pemeliharaan (hadanah) yang wajib dilaksanakan oleh orang tuanya. ${ }^{55}$ Dengan demikian orang tua memiliki kewajiban untuk merawat, memelihara dan mendidik anak, dari mulai persiapan kehamilan, memeriksakan kesehatan janin, melahirkannya secara aman, merawat, memelihara, dan mengawasi perkembangannya, serta mendidiknya supaya menjadi anak yang sehat, saleh, dan berilmu pengetahuan luas. Karena sebab itulah Islam memiliki generasi penerus yang baik dan kuat. Allah berfirman:

"Dan hendaklah takut kepada Allah orang-orang yang seandainya meninggalkan dibelakang mereka anak-anak yang lemah, yang mereka khawatir terhadap (kesejahteraan) mereka. oleh sebab itu hendaklah mereka bertakwa kepada Allah dan hendaklah mereka mengucapkan Perkataan yang benar".

Sebagai konsekuensi dari hadanah tersebut, orang tua (terutama ayah) mempunyai kewajiban untuk memberi nafkah kepada anaknya. Karena hadanah tersebut tidak mungkin berjalan secara baik tanpa adanya nafkah yang berupa makanan, pakaian, tempat tinggal, dan sarana penunjung lainnya supaya anak tumbuh dan berkembang dengan baik. bahkan dapat dikatakan bahwa kewajiban nafkah bagi anak ini masih merupakan bagian dari hadanah, karena hadanah merupakan

Adapaun rincian dari ketiga aspek tersebut pada substansinya mencakup: Pertama, hak nasab dan penyususan. Kedua, seorang anak berhak memperoleh hak pengasuhan dari kedua orang tuanya. Ketiga, anak berhak memperoleh nama yang baik. dan Keempat, anak berhak mendapatkan bimbingan dan nasihat dari kedua orang tua termasuk pertimbangan dalam memperoleh jodoh atau pasangan hidup. Lihat, Safrudin Aziz, Pendidikan Keluara; Konsep dan Strategi, Yogyakarta: Penerbit Grava Media, 2015, h. 41-42

55 Hadanah disini di pahami sebagai pemeliharaan secara menyeluruh, baik dari segi kesehatan fisik, mental, sosial, maupun dari segi pendidikan dan perkembangan pengetahuannya. 
116 M. Saeful Amri \& Tali Tulab

pemeliharaan anak baik menyangkut kesehatan fisik, mental, maupun pengetahuannya.

2. Kewajiban Anak

Apabila kewajiban orang tua dipenuhi sebagai bentuk kasih sayang kepada anak, maka sudah sewajarnya apabila seorang anak harus berbuat baik kepada orang tuanya. Kewajiban berbuat baik kepada orang tuanya pada dasarnya imbangan dari kewajiban hadanah dari orang tua, yang telah merawat anak, mulai dari sebelum lahir sampai menjadi dewasa. Al-Qur'an menyatakan:

"Dan Tuhanmu telah memerintahkan supaya kamu jangan menyembah selain Dia dan hendaklah kamu berbuat baik pada ibu bapakmu dengan sebaik-baiknya. jika salah seorang di antara keduanya atau Kedua-duanya sampai berumur lanjut dalam pemeliharaanmu, Maka sekali-kali janganlah kamu mengatakan kepada keduanya Perkataan "ah" dan janganlah kamu membentak mereka dan ucapkanlah kepada mereka Perkataan yang mulia. (Q.S, Al-Israa: 23)56 "Kami perintahkan kepada manusia supaya berbuat baik kepada dua orang ibu bapaknya, ibunya mengandungnya dengan susah payah, dan melahirkannya dengan susah payah (pula). mengandungnya sampai menyapihnya adalah tiga puluh bulan". (Q.S, Al-Ahqaf: 15)

Berbuat baik kepada orang tua ini sangat ditekankan dalam Islam. Sebagai perwujudannya, anak memiliki kewajiban untuk memberi nafkah kepada orang tua, apabila memang orang tuanya membutuhkan. Karena harta milik anak pada dasarnya adalah milik orang tuanya juga, sebagaimana disebutkan oleh hadis nabi:

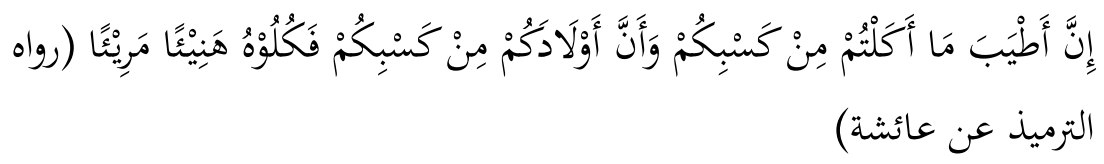

${ }^{56}$ Mengucapkan kata Ah kepada orang tua tidak dlbolehkan oleh agama apalagi mengucapkan kata-kata atau memperlakukan mereka dengan lebih kasar daripada itu.

Ulul Albab: Jurnal Studi dan Penelitian Hukum Islam 
\begin{tabular}{l|l} 
Tauhid: Prinsip Keluarga .... & 117
\end{tabular}

Artinya:

"Sebaik-baik apa yang kamu makan adalah dari usahamu, dan anak merupakan salah satu hasil usahamu, maka makanlah (dari harta anakmu) dengan enak dan lezat." (H.R. at-Tirmidzi dari Aisyah)

Berbuat baik kepada orang tua pada dasarnya dalam segala hal, tidak ada batasnya, yang membatasi adalah adanya hak anak itu sendiri. Sehinga masing-masing anak dan orang tua dalam keuarga memiliki hak dan tanggung jawab. Apabila terjadi perbedaan pendapat, maka harus dimusyawarahkan dan dibicarakan dengan baik, tentunya dengan selalu dilandasi oleh rasa kasih sayang dan saling memiliki.

\section{i) Keluarga Pembentuk Masyarakat}

Rumah tangga atau keluarga adalah suatu struktur dalam masyarakat yang bersifat khusus, saling mengikat satu sama lain. Strukturnya dapat dibangun melalui hubungan darah (natural blood ties) ${ }^{57}$ ataupun pernikahan (marriage). ${ }^{58}$ Menurut ajaran Islam, perikatan itu mengandung tanggung jawab dan sekaligus rasa saling memiliki dan saling berharap (mutual expectation). Nilai kasih sayang yang berdasarkan agama menjadikan struktur keluarga memiliki pondasi yang kokoh. Ibarat sebuah bibit tanaman, akarnya mampu tumbuh kuat ke dalam tanah, ranting-rantingnya berkembang, daun-daunnya tumbuh subur dan berkembanglah sebatang pohon yang rimbun serta memiliki batang yang kokoh.

Dalam Islam, struktur keluarga berpusat pada seorang ayah, kemudian istri. Selanjutnya hubungan vertikal ke atas (ayah, kakek, dan seterusnya) dan ke bawah (anak, cucu, dan seterusnya). Satu sama lain saling bergantung dan saling

57 Muhammad Sochib, Pola Asuh Orangtua Dalam Membantu Anak Mengembangkan Disiplin Diri, Jakarta: Rineka Cipta, 1998, h. 17.

${ }^{58}$ Puspitawati, H. Gender dan Keluarga: Konsep dan Realita di Indonesia. Bogor: PT IPB Press. 2012, h. 3 
118 M. Saeful Amri \& Tali Tulab

melengkapi. Namun bukan berarti masing-masing tidak dapat berdiri sendiri. karena dalam Islam dikenal juga struktur keluarga utama dan keluarga tambahan. Kedudukannya ditentukan oleh hukum islam dan bukan semata-mata perasaan. Namun antara posisi keluarga utama dan keluarga tambahan saling melengkapi. ${ }^{59}$

Keluarga dianggap sebagai satuan unit terpenting dalam kehidupan sosial. Selain peranannya dalam berinteraksi dan mempengaruhi satu sama-lain, keluarga juga menjadi tujuan Tuhan dalam penciptaan. Pasalnya, dalam perkawinan mewajibkan lahirnya keturunan, mencintai, mendukung, menghibur, menuntun, mendidik, menolong, dan menemani, merupakan kewajiban seseorang terhadap anggota-anggota keluarganya. Karena itu, Keluarga menempati posisi penting sebagai tujuan Ilahi. Dalam al-Qur'an kategori $d z u$-qurba atau perkerabatan sangat menonjol dalam ketentuan-ketentuan sosial Tuhan. Pendeknya, dapat dikatakan bahwa Islam menganggap keluarga mutlak perlu bagi pemenuhan tujuan Ilahi. Dan tidak akan ada tauhid tanpa pemenuhan seperti itu. ${ }^{60}$

Karakteristik keluarga dalam Islam ialah extended family (keluarga besar) ${ }^{61}$ karena Allah SWT telah menetapkan keluarga dalam bentuknya yang luas, sehingga keluarga muslim tidak

${ }^{59}$ Lihat Anshari Thayib, Struktur Rumah Tangga Islam, Risalah Gusti: ISBN 979-556-013-1, h. 3.

60 Isma'il Raji Al-Faruqi, Tauhid, (terjemah) Bandung: Penerbit Pustaka, 1988, h. 139

${ }^{61}$ Menurut wikipedia keluarga besar adalah unit sosial yang terdiri dari keluarga inti dan saudara sedarah, seringkali mencakup tiga generasi atau lebih. Kerabat juga bisa dimasukkandalam anggota keluarga besar. Sistim keluarga besar biasanya terjadi didaerah yang kondisi ekonominya membuat sulit bagi keluarga inti untuk mencapai swasembada. Pada daerah tersebut kerjasama diperlukan, baik dari kerabat patrilineal ataupun matrilineal. Keluarga besar dapat hidup bersama karena berbagai alasan, seperti untuk membantu membesarkan anak-anak, merawat saudara yang sakit dan membantu masalah keuangan. https://www.britannica.com senin, 4 desember 2017, 20.35 WIB

Ulul Albab: Jurnal Studi dan Penelitian Hukum Islam 
Tauhid: Prinsip Keluarga .... $\mid 119$

akan mengalami kesenjangan generasi karena semua generasi hidup bersama. Dengan demikian, sosialisasi akulturasi kepada generasi muda selalu lengkap, dan dapat menjamin penerusan tradisi dan budaya dengan kemungkinan adulturasi yang sangat kecil. Dari sini, masa lampau bersambung langsung dengan masa kini dan masa datang. Manfaat lain dari keluarga besar adalah bahwa ia menyediakan bagi anggotanya seorang teman yang siap dipilihnya setiap kali ia membutuhkan. Dan biasanya terdapat cukup banyak orang yang bisa dipilih, tergantung suasana hati yang ada. selalu ada seseorang yang siap diajak bermain, bercanda, berdiskusi, merenung, menangis dan berharap. Ini adalah pra-syarat yang sangat penting bagi kesehatan jiwa. Keluarga besar tidak pernah sepi dari anak-anak, orang-orang dewasa, wanita-wanita, laki-laki dan orangtua yang lebih bijaksana. ${ }^{62}$

\section{Problem Keluarga Di Barat}

Keluarga atau rumah tangga pada dasarnya adalah suatu struktur dalam masyarakat yang bersifat khusus, dan saling mengikat antara satu sama lain. Dalam sebuah negara, keluarga ibarat sebuah bibit tanaman. Jika bibit tanamannya baik dan sehat, maka akan tumbuh menjadi pohon yang berdaun rindang dan berbuah lebat. Suatu keluarga dapat berdiri kokoh apabila fungsinya berjalan dengan baik, proses organisasinya berjalan efektif, masing-masing anggota dalam struktur keluarga berfungsi secara proporsional.

Kenyataannya, pada masyarakat modern terjadi kecenderungan yang sangat memprihatinkan. Bersamaan dengan berkembangnya ilmu pengetahuan, banyak kaum perempuan yang memiliki kesempatan berpendidikan tinggi, sejajar dengan kaum laki-laki. Bahkan lahir pula gerakan-

62 Isma'il Raji Al-Faruqi, Tauhid, (terjemah) Bandung: Penerbit Pustaka, 1988, h. 142 


\section{M. Saeful Amri \& Tali Tulab}

gerakan emansipasi yang menuntut kesetaraan antara laki-laki dan perempuan dalam segala bidang. Kondisi ini melahirkan kaum perempuan yang menempati posisi karir yang tinggi, bahkan sering kali lebih tinggi dari laki-laki. Dalam posisi seperti itu, fungsi ekonomi dan perlindungan bagi seorang perempuan yang sudah menikah menjadi kabur. Masyarakat modern cenderung berfikir dan bersikap pragmatis, sehingga pernikahan lebih diutamakan sebagai fungsi seksual, reproduksi dan rekreasi. Akibatnya, rumah tangga tidak lebih dari sekedar "tempat bermalam dan melakukan kegiatan seksual". ${ }^{63}$ Bahkan selanjutnya, mereka sudah tidak lagi perduli, apakah untuk keperluan itu masih diperlukan pernikahan formal atau tidak.

Di sini penulis akan membahas pengaruh feminisme terhadap kehidupan institusi keluarga. Kemudian menjelaskan fenomena perubahan keluarga-inti (nuclear family) ke keluarga non-inti. Dan terakhir catatan berakhirnya bangunan keluarga di Barat seperti perceraian, kekerasan dalam rumah tangga dan bunuh diri.

\section{a) Bias Feminisme}

Feminis berdasarkan The New Encyclopedia of Brittanica adalah keyakinan yang berasal dari Barat, berkaitan dengan kesetaraan sosial, ekonomi dan politik antara laki-laki dan perempuan yang tersebar ke seluruh dunia lewat berbagai lembaga yang bergerak atas nama hak-hak dan kepentingan perempuan. ${ }^{64}$ Munculnya gerakan ini tidak lepas dari akar pesoalan yang ada di masyarakat, bahwa perempuan sebagai anggota masyarakat masih dianggap sebagai makhluk inferior. Sebagaimana di gambarkan oleh Simon De Behaviour dalam bukunya The Second Sex bahwa perempuan masih belum

${ }^{63}$ Anshari Thayib, Struktur Rumah Tangga Islam, Risalah Gusti: ISBN 979-556-013-1, h. 3.

64 "Feminis is the belief, largely originating in the West, in the social, economic, and political equality of the sexes, represented worldwide by various institutions commited to activity on behalf of women's right and interests."

Ulul Albab: Jurnal Studi dan Penelitian Hukum Islam 
Tauhid: Prinsip Keluarga .... $\mid 121$

menjadi manusia seutuhnya karena masih dianggap sebagai warga kelas dua dalam masyarakat. ${ }^{65}$ Oleh karena itu, inti dari gerakan ini ialah penyetaraan antara laki-laki dan perempuan dalam segala aspek, termasuk dalam institusi keluarga.

Kaum feminis menginginkan konsep keluarga yang sama rata, yakni antara suami dan istri mendapat hak dan kesempatan yang sama dalam segala hal. Kaum feminis ingin mendekonstruksi sistem keluarga yang bersifat vertical - karena dianggap patriarkhi - menjadi satu bentuk bangunan keluarga yang sifatnya horizontal. Sebab untuk dapat mencapai 'kebahagiaan' tertinggi, sebagaimana dikatakan John Stuart Mill, seorang wanita hendaknya menekan dan menghilangkan segala aspek yang ada kaitannya dengan pekerjaan domestic. ${ }^{66}$ Menurut kaum feminis, Perkawinan tradisional yang pembagian kerjanya berdasarkan gender, ${ }^{67}$ sudah tidak lagi relevan dengan kehidupan wanita modern. Untuk itu mereka menawarkan konsep baru untuk membentuk keluarga yaitu perkawinan sederajat.

Perkawinan sederajat adalah perkawinan semacam homosekseual, tanpa suami maupun istri, tanpa ayah dan ibu, yang ada adalah 'mitra' atau 'pasangan hidup' yang harus menjalani peran yang sama yang menyangkut masalah rumah, anak-anak dan ekonomi. Konsep tentang perkawinan sederajat ini membuat kebanyakan suami di Barat tidak mengharapkan istri mereka akan membersihkan rumah, merawat anak, memasang kancing baju yang lepas atau menyetrika kemeja

${ }^{65}$ Kartika Pamilia Lestari, Studi Kritis Terhadap Tafsir Feminis (Studi Pemikiran Wadud atas Kesetaraan Gender dalam Al-Qur'an) Journal Islamia, Volume III No. 5, 2010, h. 116.

${ }^{66}$ Dalam bukunya The Subjection of Women (1869) Ia mengkritik pekerjaan perempuan disektor domestic sebagai pekerjaan irrasional, emosional, dan tiranis. Dikutip dari buku Ratna Megawangi, Membiarkan Berbeda? Sudut Pandang Baru tentang Relasi Gender, Bandung: Mizan, 1999, h. 119 ${ }^{67}$ istri mengurus keluarga sedang suami pergi bekerja. 


\section{M. Saeful Amri \& Tali Tulab}

mereka. pekerjaan rumah tangga harus dilakukan berdasarkan kesepakatan mereka berdua sebelum menikah. Hal-hal yang biasa dilakukan istri ketika pacaran, seperti menyiapkan makan malam, tidak dilakukan lagi ketika sudah menikah. bahkan, setiap perintah laki-laki kepada istri dianggap pelecehan. ${ }^{68}$

Konsep lain yang ditawarkan oleh kaum feminis ialah bahwa keluarga tidak harus terdiri dari ayah, ibu, dan anak, tetapi bisa juga terdiri dari ibu dan anak. Kehadiran ayah tidak menjadi suatu keharusan. ${ }^{69}$ Begitu pula dengan kepemimpinan dalam keluarga, tidak serta merta menjadi hak milik suami tetapi istri juga memiliki hak yang sama, manakala penghasilan istri lebih besar dari suami, maka istrilah yang berhak menjadi kepala rumah tangga. Hal ini senada dengan apa yang dikatakan oleh Randal Colin dan dikutip oleh Ratna Megawangi bahwa keluarga, oleh model struktural-fungsional dijadikan institusi untuk tujuan melanggengkan sistem patriarki, kemudian Colin mengatakan bahwa sebuah keluarga ideal adalah yang berdasarkan campanionship, yang hubungannya horizontal (tidak hirarkis). ${ }^{70}$

Selain itu, menurut kaum feminis, hak reproduksi merupakan hak prerogatif dari seorang perempuan, dan oleh karena itu kaum laki-laki tidak boleh menyuruh atau bahkan memaksa mereka. ${ }^{71}$ Dalam pandangan feminis radikal perempuan yang hamil adalah perempuan yang lemah karena ia menghancurkan kebebasannya. Menurut Simone de Beauvoir,

${ }^{68}$ Danelle Crittenden, wanita salah langkah? Menggugat mitos-mitos Kebebasan Wanita Modern, Bandung: Qonita, h. 148.

69 Sebab dua majalah ternama "McCall" dan "Mademosielle" menyatakan bahwa kaum laki-laki akan segera dianggap tidak relevan lagi bagi perempuan, karena fungsi reproduksi akan diganti dengan inseminasi buatan. Lihat Warsito, Konsep Keluarga Menurut Barat, Makalah, h. 2

${ }^{70}$ Ratna Megawangi, Membiarkan Berbeda? Sudut Pandang Baru tentang relasi Gender, Bandung: Mizan, 1999, h. 85.

71 Dadang S. Ansori, Engkos Kosasih dan Farida sarimaya, membincangkan feminisme, Bandung: Pustaka Hidayah, 1007, h.7

Ulul Albab: Jurnal Studi dan Penelitian Hukum Islam 
Tauhid: Prinsip Keluarga .... $\mid 123$

"perkawinan" dimaksudkan untuk menghalangi wanita mendapatkan kebebasan yang dinikmati pria. Tugas perempuan hanya sekedar memuaskan kebutuhan seks suami dan mengurus rumah tangga. Jika perempuan hanya menjadi istri dan ibu yang mengurus keluarga, maka keputusan menikah adalah kekalahan. ${ }^{72}$ Itulah rumusan keluarga ideal menurut kaum feminis radikal, yaitu Sebuah keluarga tanpa kelas yang mengangkat semangat kesetaraan dan kesederajatan dengan menghapus dua sumber penindasan yaitu, peran domestik dan sistem patriarki yang menempatkan laki-laki pada sistem yang menguntungkan. ${ }^{73}$

\section{b) Fenomena Keluarga}

Sejumlah sosiolog Barat berpendapat bahwa sejak awal abad keduapuluh, arti lembaga keluarga mulai bergeser. Akibatnya, keterikatan sebuah lembaga keluarga terhadap fungsi-fungsi pokonya secara utuh menjadi tercabut. Seperti dikatakan oleh seorang sosiolog Amerika bernama William F. Ogbum, bahwa fungsi keluarga yang menonjol tinggal seks dan prokreasi (melanjutkan keturunan). Bahkan ahli ilmu sosial lainnya, Pitirn A. Sorokin, berpendapat bahwa banyak keluarga modern di dunia Barat terjerembab dalam pandangan pragmatis yang menilai keluarga hanyalah "a mere overnight parking place mainly for sex relationship". Sekedar tempat tinggal di malam hari, utamanya untuk berhubungan seks. Faktor pengikat paling pokok dalam keluarga, yaitu kasih sayang menjadi hilang. ${ }^{74}$ Akibatnya, angka perceraian di Barat lebih tinggi dibanding Negara-negara Islam.

72 Danelle Crittenden, wanita salah langkah? Menggugat mitos-mitos Kebebasan Wanita Modern, Bandung: Qonita, h. 148.

73 Dadang S. Ansori, Engkos Kosasih dan Farida sarimaya, membincangkan feminisme, Bandung: Pustaka Hidayah, 1007, h.170

${ }^{74}$ Anshari Thayib, Struktur Rumah Tangga Islam, Risalah Gusti: ISBN 979-556-013-1, h. 115 
124 M. Saeful Amri \& Tali Tulab

Alven Tofler dalam buku The Third Wave menggambarkan fenomena peralihan keluarga. Pada mulanya struktur keluarga di Barat menganut sistim keluarga besar yang kemudian beralih ke sistim keluarga inti (nuclear family). ${ }^{75}$ Ia mengistilahkannya dengan sebutan peralihan gelombang pertama ke gelombang kedua. Namun pasca krisis umum industrialisme, sistim keluarga-inti ini beralih ke gelombang ketiga yang baru, yang berarti bahwa keluarga-inti sudah tidak lagi dapat dipakai sebagai model yang ideal bagi masyarakat, tetapi sebagai salah satu dari bentuk keluarga yang berkembang di masyarakat. Fakta menunjukan bahwa Amerika Serikat sebagian besar penduduknya sudah hidup diluar bentuk keluarga-inti yang klasik itu. 7 persen dari seluruh penduduknya masih menganut bentuk keluarga-inti, sedang 93 persen sudah tidak lagi menyesuaikan dengan sistim keluarga ini.

Pertama-tama, terjadi suatu ledakan penduduk "solo" yakni seseorang yang hidup sendiri, tinggal di luar lingkungan keluarga. Antara tahun 1970 dan 1978 jumlah penduduk yang hidup sendiri yang berumur 14 sampai 34 tahun hampir tiga kali lipat di Amerika Serikat, meningkat dari 1,5 juta mencapai 4,3 juta orang. Sekarang seperlima dari semua rumah tangga di Amerika serikat terdiri dari orang yang hidup 'solo' sendiri. Mereka ini bukanlah orang-orang yang pernah kecewa atau patah hati yang kemudian hidup menyendiri. Tetapi sengaja memilih hidup sendiri, setidak-tidaknya untuk sementara. Berkata seorang wanita yang menjadi penasehat seorang perwakilan kota seattle, "saya akan mempertimbangkan suatu perkawinan jika telah bertemu orangnya yang tepat, namun untuk itu saya tidak mau mengorbankan karir saya", dia

75 Yang dimaksud keluarga inti (nuclear family) disini ialah suami pencari nafkah, istri mengatur rumah tangga dan beberapa anak. Bentuk keluarga yang seperti inilah yang diingini oleh peradaban gelombang kedua, dan dibikinnya menjadi dominan serta disebarkannya keseluruh dunia.

Ulul Albab: Jurnal Studi dan Penelitian Hukum Islam 
\begin{tabular}{l|l} 
Tauhid: Prinsip Keluarga .... & 125
\end{tabular}

memilih hidup sendiri (melajang). Menurut Ahli sensus, Arther Norton, "dia telah ikut menciptakan suatu tahap kehidupan peralihan yang telah menjadi bagian dari siklus kehidupan seseorang yang telah disetujui umum".

Selain itu berkembang juga kehidupan orang-orang yang hidup bersama tanpa menikah, tanpa menghiraukan formalitas hukum, yang dikenal dengan sebutan 'cohibitation'. Jumlah kelompok ini meningkat lebih dari dua kali lipat dalam waktu sepuluh tahun terakhir. Praktek "kumpul kebo" telah begitu umum berlaku dimasyarakat, sehingga Departemen Perumahan dan Pembangunan Kota Amerika Serikat terpaksa mengabaikan tradisi dan mengubah berbagai peraturannya untuk mengizinkan pasangan-pasangan seperti itu untuk menempati perumahan umum.

Perubahan lainnya ialah tumbuhnya sejumlah pasangan yang dengan sadar memilih apa yang disebut gaya hidup "bebas anak". Menurut James Ramsey, ahli riset pada Center for Policy Research, "kita sekarang ini melihat suatu pergeseran besarbesaran dari rumah tangga yang terpusat pada anak ke rumah tangga yag terpusat pada orang dewasa." Menurutnya, Pada pergantian abad yang lalu hanya terdapat sedikit orang yang hidup sendiri dalam masyarakat, dan secara relatif hanya sedikit orang tua yang hidup lama setelah anak bungsunya meninggalkan rumah. Jadinya, sebagian besar rumah tangga pada waktu itu sebenarnya terpusat pada anak. Namun sebaliknya, sejak tahun 1970, hanya satu dari tiga orang dewasa tinggal dirumah dengan anak yang berumur di bawah 18 tahun di Amerika.

Sekarang ini timbul berbagai organisasi yang menganjurkan kehidupan 'bebas anak' yang pada banyak negeri industri sikap enggan mempunyai anak ini telah meluas. Pada tahun 1960 hanya 20 persen dari wanita Amerika berusia di bawah tigapuluh tahun yang 'pernah menikah' samasekali tidak mempunyai anak. Pada tahun 1975 angka ini menanjak sampai 
126 M. Saeful Amri \& Tali Tulab

$32 \%$, meningkat $60 \%$ dalam waktu lima belas tahun. Di Amerika muncul organisasi bernama National Alliance for Optional Parenthood, ${ }^{76}$ yang bersikap keras untuk melindungi hak-hak mereka yang tidak mempunyai anak dan gigih berjuang melawan propaganda kaum yang pro- kelahiran anak.

Di seluruh Eropa banyak pasangan yang juga dengan sengaja memilih hidup tanpa anak. Misalnya, di Bonn, Jerman Barat. Pasangan bernama Theo dan Agnes Rohl. Theo bekerja sebagai pegawai kota, sedangkan Agnes bekerja sebagai sekretaris, keduanya tinggal bersama dirumah yang kecil, namun dalam keadaan yang berkecukupan, sekali-kali pergi berlibur ke kalifornia atau perancis selatan. Bagi mereka mempunyai anak akan berakibat pada perubahan pola kehidupan mereka yang sudah nyaman. mereka mengatakan, "kami tidak memikirkan untuk mempunyai anak. Kami sudah terbiasa dengan gaya hidup seperti ini, dan kami senang menjadi orang yang bebas."

Dari sini, perlu kiranya kita merenungkan perkataan dari sosiologi Barat bernama Jessie Bernard, yang mengatakan bahwa, "Karakteristik yang paling penting pada perkawinan masa depan ialah terletak pada serangkaian pilihan yang tersedia bagi setiap orang untuk menentukan sendiri bentuk yang diinginkannya dalam hubungannya dengan orang lain."77

${ }^{76}$ Pada mulanya organisasi ini benama The National Organization for Non-Parents (N.O.N) yang didirikan di Palo Arto, California, oleh Ellen Peck dan Shirley Radl pada tahun 1972, dengan tujuan untuk meyebarkan gagasan bahwa orang bisa memilih untuk tidak memiliki anak. Kemudian diawal tahun 1980 organisasi ini berubah nama menjadi The National Alliance for Optional Parenthood, dengan tujuan yang sama yakni untuk mendidik masyarakat tentang orangtua yang bukan orangtua sebagai pilihan gaya hidup yang sah, mendukung mereka yang memilih untuk tidak mempunyai anak, meningkatkan kesadaran akan masalah kelebihan populasi, dan membantu kelompok lain yang menyuarakan hal yang sama. http://en.m.wikipedia.org jum'at 1 desember 2017, 19:45 wib.

77 Ibid, h. 88-89

Ulul Albab: Jurnal Studi dan Penelitian Hukum Islam 


\section{c) Runtuhnya Bangunan Keluarga}

Dalam jurnal ISLAMIA edisi ketiga, Elizabeth Diana menjelaskan masalah besar yang tengah dihadapi oleh Amerika Serikat yaitu masalah keluarga. Menurutnya ada dua faktor utama atas retaknya sistem sebuah keluarga di Negara maju tersebut. Pertama, sebab pernikahan yang hanya terfokus untuk mencari kesenangan daripada berpikir tentang tanggung jawab. ${ }^{78}$ Kedua, sebab putusnya sistem keluarga besar yang utuh. Akibat dari sebab yang pertama ialah rumaha tangga yang berujung pada perceraian dan kekerasan dalam rumah tangga. Sedangkan sebab yang kedua mengakibatkan berkembangnya kasus bunuh diri serta pemerkosaan dikalangan remaja sebab kurangnya perhatian orang tua dan keluarga.

\section{Perceraian}

Persoalan pertama dapat dilihat dari majalah Better Homes and Gardens, yaitu sebuah majalah di Amerika yang menggulirkan satu pertanyaan kepada pembacanya: "apakah anda pikir kehidupan berkeluarga di Amerika Serikat tengah menghadapi banyak permasalahan?". Sebanyak 7,6\% koresponden mengiyakan pertanyaan tersebut dan $85 \%$ dari pembacanya menyatakan bahwa harapan mereka untuk merasakan hidup yang bahagia dalam keluarga belum terpenuhi. Sedangkan majalah Amerika lainnya, Newsweek mempublikasikan dari hasil surveinya bahwa sekitar separuh

${ }^{78}$ Beberapa pasangan menikah ketika mereka sepakat untuk mencari kesenangan dan kenikmatan saja. sehingga apabila kehidupan perkawinan tidak lagi dapat memberikan apa yang mereka cari, maka mereka akan memilih jalan mereka sendiri-sendiri. Hal ini telah mengakibatkan erosi kesakralan lembaga keluarga pernikahan. Perceraian sebagai konsekwensinya menjadi sutau hal yang biasa. Anak-anak siapa saja yang terlahir dari pasangan seperti itu, hanya sedikit lebih beruntung daripada anak-anak yatim piatu, sebab mereka masih memiliki orang tua. 
128 M. Saeful Amri \& Tali Tulab

dari semua lembaga pernikahan di Amerika berakhir di meja perceraian. ${ }^{79}$

Fakta perceraian terbaru (minimal 5 tahun terakhir)

Selain itu praktek kekerasan dalam rumah tangga juga kian merebak dan terus berkembang, baik penganiayaan fisik, psikis maupun seks yang bertujuan menunjukan kekuatan dan mengendalikan orang lain. Diperkirakan sekitar 3,2 juta anakanak Amerika menyaksikan kekerasan dalam rumah tangga setiap tahunnya Kekerasan Dalam Rumah Tangga (KDRT)

Kekerasan dalam rumah tangga di Amerika merupakan problem sosial yang sangat serius, hal ini bisa terlihat dari meratanya fakta-fakta kekerasan dalam rumah tangga tersebut. Dari 960.000 aksi kekerasan yang terjadi setiap tahunnya pada pasangan intim maupun suami istri, diperkirakan mencapai 3 juta wanita mengalami penyiksaan fisik yang dilakukan oleh suami maupun pacar lelakinya. ${ }^{80}$ Sekitar sepertiga wanita Amerika (31\%) dinyatakan mengalami penyiksaan fisik maupun seksual oleh suami atau pacarnya, seperti dilaporkan oleh commonwealth fund survey pada tahun $1998 .{ }^{81}$

Menurut The National Violance Againts Women Survey, dalam rentang waktu November 1995 hingga mei 1996, hampir $25 \%$ wanita Amerika dilaporkan telah diperkosa atau mengalami penyiksaan fisik oleh suami atau mantan suaminya, teman kumpul kebo (cohabiting partner) maupun pacarnya. ${ }^{82}$ Pada tahun 2001, lebih dari setengah juta wanita Amerika

${ }^{79}$ Elizabeth Diana Dewi, Bias Paham Feminisme Barat, Journal Islamia, Volume III No. 5, 2010, h. 91

${ }^{80}$ The commonwealth fund, Health Concern Across a Women's Lifespan: 1998 Survey of Women's Health, may 1999

${ }^{81} \mathrm{Ibid}$

82 The Centers for Disease Control and Provention and The National Institue of Justice, Extent, Nature, and Concequence of Intimate Partner Violance, July 2000.

Ulul Albab: Jurnal Studi dan Penelitian Hukum Islam 
\begin{tabular}{l|l} 
Tauhid: Prinsip Keluarga .... & 129
\end{tabular}

(588.490) adalah korban kekerasan yang tegolong tidak sampai mematikan, yang dilakukan oleh partner intimnya. ${ }^{83}$

Selain itu, kekerasan juga kerap terjadi dikalangan para pemuda. U.S Departement of Education melaporkan bahwa dalam kurun waktu satu tahun yakni selama tahun ajaran 1996-1997, diperkirakan 4.000 insiden pemerkosaan atau penganiayaan seksual terjadi dilingkungan sekolah di seluruh negara bagian. ${ }^{84}$ $40 \%$ wanita berumur antara $14 \mathrm{~s} / \mathrm{d} 17$ tahun dinyatakan telah mengetahui teman sebanyanya yang selalu menerima pukulan dari pacarnya. Dan Satu diantara lima wanita pelajar SMU dilaporkan telah mengalami penyiksaan fisik dan atau seksual oleh pacar mereka.

Tidak hanya itu, kekerasan dalam rungga bukan Cuma terjadi pada perempuan, ataupun remaja, tetapi juga kerap menimpa anak-anak. Dalam survey nasional, terdapat lebih dari 6.000 keluarga di Amerika, 50\% kaum lelaki sering menganiaya istri dan anak-anak mereka. Dalam U.S Departement of Justice disebutkan lebih dari separoh korban wanita penganiayaan pasangan intim hidup dalam rumah tangga bersama anak-anak yang berumur dibawah 12 tahun. ${ }^{85}$

\section{Bunuh Diri dan Pemerkosaan}

Sebab kedua hancurnya sistem keluarga di Barat adalah karena putusnya sistem keluarga besar yang utuh. Hal ini dapat ditelusuri dari adanya gejala-gejala meningkatnya jumlah orang tua bahkan kakek nenek lanjut usia yang dikirim ke panti-panti jompo dan hidup terpisah dari keluarga mereka sendiri. Padahal dalam sistem keluarga besar, kakek nenek pasti ada untuk memperhatikan cucu mereka. Tetapi dalam budaya masyarakat

${ }^{83}$ The commonwealth fund, Health Concern Across a Women's Lifespan: 1998 Survey of Women's Health, may 1999

${ }^{84}$ U.S. Departement of Education, Violance and Disiplin Problem in U.S Public School: 1996-1997

${ }^{85}$ U.S. Departement of Justice, Violance by Intimates: Analysis of Data on Crimes by Current or Former Spouse, Boyfrriends, and Girlfriends, March 1998. 
130 M. Saeful Amri \& Tali Tulab

Barat, tempat mereka bukan lagi di tengah-tengah keluarga mereka.

Saat ini fokus perhatian orang tua tidak lagi tertuju kerumah, $^{86}$ karenanya anak-anak di negara Barat telah kehilangan sosok seorang ibu. Sebab sebagaimana ayahnya, ibunya lebih memilih untuk bekerja di kantor. Selain itu mereka juga harus kehilangan sosok kakek neneknya. Karena mereka pun telah dikucilkan di panti-panti jompo. Anak-anak dikeluarga seperti itu biasanya tidak mempunyai emosi yang seimbang sehingga mereka bisa saja berpikir pada satu titik bahwa tidak ada gunanya lagi melanjutkan hidup.

Sebuah laporan yang diterbitkan majalah TIME bertemakan Teen Suicide (Bunuh diri dikalangan Remaja) menjelaskan bahwa kecenderungan bunuh diri di kalangan remaja yang berumur antara $10 \mathrm{~s} / \mathrm{d} 20$ tahun meningkat sangat tajam di Amerika Serikat, yaitu bertambah tiga kali lipat pertahunnya sejak 1950. Pada tahun 1985, dari 100.000 orang tercatat 60 orang dewasa dan 60 remaja nekat melakukan bunuh diri. ${ }^{87}$

Selain bunuh diri, angka pemerkosaan yang terjadi dikalangan para remaja juga memprihatinkan. Tiga dari empat wanita dilaporkan telah mengalami pemerkosaan dan atau penganiayaan fisik sejak berumur 18 tahun yang dilakukan oleh mantan atau kekasihnya sekarang. 88 Pada tahun 2000 48\% perkosaan dan serangan seksual dilakukan terhadap anak-anak berusia 12 tahun. Sedang pada tahun 2001 sebanyak 41.740

${ }^{86}$ Dulu seorang ibu senantiasa berada dirumah untuk tetap dapat memperhatikan anak-anaknya. Tetapi sekarang, ia lebih memilih bekerja di luar rumah sebagaimana suaminya. Elizabeth Diana Dewi, Bias Paham Feminisme Barat, Journal Islamia, Volume III No. 5, 2010, h. 91

${ }^{87}$ Ibid., 95.

${ }^{88}$ U.S. Departement of Justice, Violance by Intimates: Analysis of Data on Crimes by Current or Former Spouse, Boyfrriends, and Girlfriends, March 1998.

Ulul Albab: Jurnal Studi dan Penelitian Hukum Islam 
Tauhid: Prinsip Keluarga .... $\mid 131$

wanita telah menjadi korban pemerkosaan yang dilakukan oleh pasangan intimnya. ${ }^{89}$

Problematika kehidupan yang menimpa anak-anak dan remaja di Barat tidak lepas dari fungsi dan sistem keluarga yang rapuh. Sebab mereka kehilangan satu bentuk perlindungan atau naungan sebenarnya yang mutlak keberadaannya dalam suatu keluarga. Sebab lain adalah perkembangan jiwa mereka yang tidak sehat karena hilangnya kepedulian dan kasih sayang dalam lingkaran sebuah keluarga. Jadi hancurnya keutuhan keluarga sebagai suatu unit sosial harus diakui sebagai faktor utama kecenderungan bunuh diri dan perkosaan pada kaum remaja masa kini.

\section{Kesimpulan}

Islam memandang pernikahan sebagai media pembentuk keluarga yang bangunanya harus didasarkan pada Tauhid, yakni tujuan tuhan dalam pembentukan keluarga sehingga panduannya jelas, kokoh, dan ber-maslahah yakni dengan memenuhi kewajiban oleh setiap anggota keluarga sehingga hak-hak anggota keluarga yang lain terpenuhi. Hasilnya, kehidupan rumah tangga tercipta untuk selamanya, dan bukan untuk sementara waktu saja.

Sedangkan di Barat sebaliknya, bangunan keluarganya rapuh. Sebab prinsip-prinisip dalam berkeluarga sudah tidak ada lagi. Tujuan perkawinan hanya untuk mendapatkan kesenangan semata tanpa memperhatikan kewajibankewajibannya. Begitu mendapatkan keadaan yang tidak menyenangkan, mereka tidak dapat mentolerir, akhirnya pernikahanpun berakhir. Selain itu bentuk keluarga besarpun pecah menjadi keluarga inti, sehingga setiap keluarga hanya

89 Bureau of Justice Statistic Crime Data Brieft, Intimate Partner Violance, 1993-2001, February 2003 
$132 \mid$ M. Saeful Amri \& Tali Tulab

berfokus kepada keluarganya masing-masing tanpa merasa terikat dengan keluarga yang lain.

Dampaknya setiap orang tua di Barat akan dipindahkan ke panti-panti jompo. Dari situ, terjadi gap dalam keluarga, yakni antara generasi lama dengan generasi mendatang, antara Anak dan kakek-neneknya. Kesenjangan ini berakibat pada hilangnya tradisi atau budaya di dalam suatu institusi keluarga. Oleh karena itu, hancurnya keutuhan keluarga sebagai suatu unit sosial adalah akibat dari hilangannya satu bentuk perlindungan serta kepedulian dan kasih sayang dalam lingkaran sebuah keluarga.

\section{Daftar Pustaka}

Al-Faruqi, Isma'il Raji. 1988. Tauhid. (terjemah) Bandung: Penerbit Pustaka.

al-Ghazali, Abu Hamid. t.h. Ihyā 'ulüm al-Dìn (t,t: t.p), jilid III.

Ansori Dadang S., et.al. 1997. Membincangkan Feminisme. Bandung: Pustaka Hidayah.

Arif, Syamsuddin. 2017. Islam dan Diabolisme Intelektual. Jakarta: INSIST.

Aziz, Safrudin. 2015. Pendidikan Keluarga: Konsep dan Strategi. Yogyakarta: Penerbit Gava Media.

Basyir, Azar. 1996. Hukum Perkawinan Islam. Yogyakarta: Perpustakaan Fakultas Hukum UII.

Bureau of Justice Statistic Crime Data Brieft, Intimate Partner Violance, 1993-2001, February 2003

Crittenden, Danelle. 2002. Wanita Salah Langkah? Menggugat Mitos-Mitos Kebebasan Wanita Modern. Bandung: Qonita.

Departemen Agama RI. 2008. Membangun Keluarga Harmoni (Tafsir Al-Qur'an Tematik). Jakarta: Departemen Agama RI.

Dewi, Elizabeth Diana. Bias Paham Feminisme Barat. Jurnal Islamia. Volume III No. 5, 2010. 
\begin{tabular}{l|l} 
Tauhid: Prinsip Keluarga .... & 133
\end{tabular}

Hamid Fahmi Zarkahsyi. 2010. Liberalisasi Pemikiran Islam (Gerakan bersama Missionaris, Orientalis, dan Kolonialis. Ponorogo: CIOS-ISID-Gontor.

Ibrahim, Hosen. 1971. Fiqh Perbandingan dalam Masalah Nikah dan Rujuk. Jakarta: Ihya Ulumuddin.

Lestari, Kartika Pamilia. Studi Kritis Terhadap Tafsir Feminis (Studi Pemikiran Wadud atas Kesetaraan Gender dalam Al-Qur'an). Jurnal Islamia. Volume III No. 5. 2010.

Megawangi, Ratna. 1999. Membiarkan Berbeda? Sudut Pandang Baru tentang Relasi Gender. Bandung: Mizan.

Mubarak, Achmad. 2016. Psikologi Keluarga. Malang: Madani.

Muslikhati, Siti. 2004. Feminisme dan Pemberdayaan Perempuan dalam Timbangan Islam. Jakarta: Gema Insani.

Puspitawati, H. 2012. Gender dan Keluarga: Konsep dan Realita di Indonesia. Bogor: PT IPB Press.

Sajuti, Thalib. Kuliah Hukum Islam II Pada Fakultas Hukum UI (Kuliah ke III). Jakarta: 1997.

Shihab, Quraish. 2007. Pengantin Al-Qur'an. Jakarta: Lentera Hati.

Sochib, Muhammad. 1998. Pola Asuh Orangtua Dalam Membantu Anak Mengembangkan Disiplin Diri. Jakarta: Rineka Cipta. Syarifuddin, Amir. 2006. Hukum Perkawinan Islam di Indonesia (Antara Fiqh Munakahat dan Undang-undang Perkawinan). Jakarta: Kencana Prenamedia Group.

Thayib, Anshari. Struktur Rumah Tangga Islam. Surabaya: Risalah Gusti.

The Centers for Disease Control and Provention and The National Institue of Justice, Extent, Nature, and Concequence of Intimate Partner Violance, July 2000.

The commonwealth fund, Health Concern Across a Women's Lifespan: 1998 Survey of Women's Health, may 1999.

Tofler, Alvin. 1992. The third wave. Jakarta: PT Pantja Simpati.

U.S. Departement of Education, Violance and Disiplin Problem in U.S Public School: 1996-1997 
134 M. Saeful Amri \& Tali Tulab

U.S. Departement of Justice, Violance by Intimates: Analysis of Data on Crimes by Current or Former Spouse, Boyfrriends, and Girlfriends, March 1998.

Warsito, Konsep Keluarga Menurut Barat, Makalah.

William J., Goode. 1983. The Family. terjemahan ke dalam bahasa Indonesia oleh Dra. Lailahanoum Hasyim. Jakarta: Penerbit PT Bina Aksara.

http://en.m.wikipedia.org jum'at 1 desember 2017, 19:45 WIB https://www.britannica.com senin, 4 desember 2017, 20.35 WIB 